\title{
THE EFFICACY OF SOME NATURAL AND CHEMICAL FORMULATIONS AGAINST THE HIBISCUS MEALYBUG, MACONELLICOCCUS HIRSUTUS AND ITS NATURAL ENEMIES IN THE LABORATORY AND FIELD IN EGYPT
}

\author{
SHAABAN ABD-RABOU AND MONA MOUSTAFA \\ Plant Protection Research Institute, Agricultural Research Center, Dokki, Giza \\ Shaaban59@yahoo.com
}

(Manuscript received 3 October 2010 )

\begin{abstract}
The hibiscus mealybug, Maconellicoccus hirsutus (Green) (Hemiptera: Pseudococcidae) is an important pest on grapevine, guava, soybean, peanut and other plants in various locations in Egypt. In addition to debilitating the host plant due to the loss of sap, the resulting honeydew becomes covered in a thick mat of sooty mould, severely reducing respiration and photosynthesis. This paper presents the results of laboratory and field tests on the effect of natural compounds (Biofly and NeemAzal) and the formulated compounds (Super Mesrona oil and Sumithion) on M. hirsutus and its parasitoids and predators. The laboratory tests indicated that the effect of Sumithion on the mealybug and its natural enemies ranged from $58-98 \%$, Biofly from $15-80 \%$, Super Mesrona oil from $24-98 \%$ and NeemAzal from $17-73 \%$, respectively. For the field tests the results indicated that Biofly gave moderate results against nymphs of $M$. hirsutus, with mean mortality for the two years of $41 \& 36 \%$ after 3 days, $55 \& 51 \%$ after 7 days and $58 \& 53 \%$ after 15 days, while the parasitoids Anagyrus kamali and A. pseudococci (Hymenoptera: Encyrtidae) and Allotropa mecrida (Hymenoptera: Platygastridae) had mortalities of $61 \& 48 \%, 66$ \& 59\%, 55 \& 47\% respectively for the same periods in the 2 years. The predators Scymnus seriacus (Coleoptera: Coccinellidae) had 50 \& $37 \%$ mortality and Chrysopa vulgaris aegyptica (Neuroptera: Chrysopidae) had $53 \& 41 \%$ mortality after 15 days respectively. On the other hand, Sumithion had high efficacy against nymphs of M. hirsutus, with percent reductions of $95 \%, 96 \%$ and $91 \%$ for 2008 and $91 \%$, $93 \%$ and $88 \%$ for 2009 . The parasitoids A. kamali, A. pseudococci and $A$. mecrida had mortalities of $95 \& 93 \%, 90 \& 87 \%$ and $93 \&$ $90 \%$ respectively after 15 days in the two years, while the predators, Scymnus seriacus and Chrysopa vulgaris aegyptica had percent reductions of $88 \& 84 \%$ and $85 \& 82 \%$ after 15 days in the 2 years.
\end{abstract}

\section{INTRODUCTION}

The hibiscus mealybug Maconellicoccus hirsutus (Green) ( Hemiptera : Pseudococcidae) is one of the most dangerous pest attacking different economic crops. It attacks 125 host plants ( Mani 1989). The economic importance of this pest observed by (Williams 1996). The hibiscus mealybug, is an imporant pest on grapevine, guava, soybean and some other plants raised in newly reclaimed areas in different locations in Egypt (Abd-Rabou et al. 2007). In addition to debilitating the 
82 THE EFFICACY OF SOME NATURAL AND CHEMICAL FORMULATIONS AGAINST THE HIBISCUS MEALYBUG, MACONELLICOCCUS HIRSUTUS AND ITS NATURAL ENEMIES IN THE LABORATORY AND FIELD IN EGYPT

host plant due to the loss of sap, the resulting honeydew becomes covered in a thick mat of sooty mould, severely reducing respiration and photosynthesis. The natural enemies and their role in biological control of this pest have been attracted many workers all over the world including Egypt, Mani 1989; Abd-Rabou 2000; Abd-Rabou 2005 and Reddy et al. 2009. In addition Noyes and Hayat (1994) recorded 21 parasitoids are known to attack the hibiscus mealybug world wide. Ten of them in Egypt (Abd-Rabou et al. 2007). The effect of the insecticides on the hibiscus mealybug, M. hirsutus and its natural enemies has been studied by Ghose (1970), Babu and Azam (1987), Mani and Thorntakarya (1988), Srinivasan and Sundarababu (1989), Mani and Krishnamoorthy (1990), Satyanarayana et al. (1991), Persad and Khan (2000), Muthukrishnan et al. (2005) and Raguraman and Premalatha (2006).

The aim of this work is to test the efficacy of some natural compound compared with a chemical compound on the hibiscus mealybug, M. hirsutus and its natural enemies under both laboratory and field conditions.

\section{Materials and Methods}

\section{Laboratory experiments}

\subsection{Mass rearing of Maconellicoccus hirsutus and its natural enemies}

M. hirsutus was reared on squash under laboratory conditions $\left(23 \pm 2^{\circ} \mathrm{C}\right.$ and $60 \pm 5 \%$ R.H.) . Culture of the natural enemies was started that emerged from the collected specimens from the field and the colony was reared $M$. hirsutus feeding on was reared on squash. The laboratory conditions were $25-27 \mathrm{C}^{\circ}$ and $65-70 \mathrm{R} . \mathrm{H} \%$.

\section{2. Tested commercial formulation}

The following four compounds were tested: Biofly, an entomopathogenic fungi ( $3 \mathrm{X} 10^{7} \mathrm{c}$. fu $1 \mathrm{ml}$ ), containing the fungus Beauveria bassiana, used at a rate of 2 $\mathrm{ml} /$ liter of water, NeemAzal, a botanical extract containing $1 \%$ Azadirachtin a (10 $\mathrm{g} /$ liter) from the neem tree, Azadirachta indica (Meliaceae), applied at a rate of 2 $\mathrm{ml} /$ liter of water, Sumithion $50 \%$ EC a chemical pesticide was applied at a rate of 2 $\mathrm{ml}$ / liter of water and Super Misrona 95\% EC, a local mineral oil, containing 95\% paraffinic oil $\mathrm{w} / \mathrm{w}$, unsulfonated residue content reached $92 \%$, applied at a rate of 20 $\mathrm{ml} /$ liter of water.

\section{3. Tested methods}

The laboratory experiments were carried out in the laboratory of Plant Protection Research Institute, ARC, Dokki, Giza. The method of indirect exposure was used to evaluate the effect of the four compounds on the $M$. hirsutus and its natural enemies throughout the present investigation. Five concentrations of Biofly , NeemAzal, Super Mesrona oil and Sumithion were used; one hundred individuals were sprayed in each concentration for five seconds. Mealybug individuals were divided into 
five replicates. One hundred individuals sprayed by clean water as untreated check (control). The individuals of mealybugs were transferred to clean wide plastic dishes, which were then covered with muslin cloth held in position by rubber bands. After 24 hours the alive of $M$. hirsutus and its natural enemies were counted.

\section{4. Statistical analysis}

In laboratory tests, the mortality percentages were calculated and corrected for natural mortalities by Abbott's formula (1925). The corrected percent mortalities were statistically computed according to Finney (1971) and plotted on probit analysis paper. The tested compounds were compared for their efficiency on the predators and parasitoids and prey according to their $\mathrm{LC}_{50}, \mathrm{LC}_{90}$ and slopes of the toxicity lines.

\section{Field experiments}

The experiments were carried out to evaluate of the four compounds (Biofly , NeemAzal, Super Mesrona oil and Sumithion) on M. hirsutus and its natural enemies on grape were carried out at El-Minya Governorate. When the numbers of $M$. hirsutus and its natural enemies were high during September of the two seasons, 2008 and 2009.

2.1. The experiments comprised 4 compounds: Biofly, an entomopathogenic fungi ( $3 \times 10^{7} \mathrm{c}$. fu $1 \mathrm{ml}$ ), containing the fungus Beauveria bassiana, used at a rate of $2 \mathrm{ml} /$ liter of water, NeemAzal, a botanical extract containing $1 \%$ Azadirachtin a (10 $\mathrm{g} /$ liter) from the neem tree, Azadirachta indica (Meliaceae), applied at a rate of 2 $\mathrm{ml} /$ liter of water, Sumithion $50 \%$ EC a chemical pesticide was applied at a rate of 2 $\mathrm{ml} /$ liter of water and Super Misrona 95\% EC, a local mineral oil, containing 95\% paraffinic oil $\mathrm{w} / \mathrm{w}$, unsulfonated residue content reached $92 \%$, applied at a rate of 20 $\mathrm{ml} /$ liter of water.

Each treatment conducted in 1/4 Fadden. One quarter of Fadden was also used as an untreated check (control). Spraying was applied at the rate of per plant which was accomplished by the use of sprayer of 600 liter capacity. Pre-spraying counts were made just before spraying. The post spraying counts were made after 3, 7 and 15 days from application. Random samples of 30 leaves and 15 twigs were picked up from each replicate. A total number of 30 infested leaves and 15 twigs for each treatment thus examined. By means of a stereoscopic microscope insect was inspected.

\subsection{Statistical analysis}

The percent reduction of infestation was statistically calculated according to the equation of (Henderson and Tilton 1955).

$$
\begin{aligned}
& \mathrm{Ta} \times \mathrm{Cb} \\
& \% \text { mortality }=100 \text { [1- ------------ }
\end{aligned}
$$


Where: $\mathrm{Ta}=$ Post treatment insect counts, $\mathrm{Cb}=$ Untreated insect count before treatment

$\mathrm{Tb}=$ Pretreatment counts, $\mathrm{Ca}=$ Untreated insect count after treatment.

\section{RESULTS AND DISCUSSION}

\section{Laboratory Experiments}

Data presented in Table (1) showed the potency of three natural compounds namely (Biofly, NeemAzal and Super Mesrona oil) compared with Sumithion against the nymphs and adult females using direct exposure technique. Tabulated data indicated that, the potency of the tested compounds was varied tremendously due to the nature of the tested compounds, the used concentration and the tested stage. As a general trend, data proved that at any of the tested compound the higher the concentration, the higher was the rate of mortality and vice versa. According to of the data the $\mathrm{LC}_{50}$ and $\mathrm{LC}_{90}$ (Table 1), Sumithion proved to be the most effective compound, followed by Super Mesrona oil, Neem Azal while Biofly came in the last category. The slope of line is useful to clarify the homogeneity of nymphs and adult of M. hirsutus. While parasitoids and predators of M. hirsutus, according to the $\mathrm{LC}_{50}$ and $\mathrm{LC}_{90}$, Sumithion proved to be the most effective compound, followed by Super Mesrona oil, Biofly while NeemAzal came in the last category. The slope of line is useful to clarify the homogeneity of the parasitoids . kamali and A. pseudococci and A. mecrida and predators $S$. seriacus and C. vulgaris aegyptica of M. hirsutus, which collected from the field to different compounds.

\section{Field experiments}

The experiments were carried out to evaluate of the four compounds Biofly , NeemAzal, Super Mesrona oil and Sumithion on M. hirsutus and its natural enemies on grape were carried out at El-Minya Governorate. When the numbers of M. hirsutus and its natural enemies were high during the two seasons, 2008-2009.

\subsection{The second season (2008)}

In the first season (2008), the pre-spraying counts of adults and nymphs of $M$. hirsutus were 780-860 and 2210-2293 / 30 leaves, respectively and the numbers of $A$. kamali and $A$. pseudococci and $A$. mecrida were 188-199, 155-166 and 185-215 /30 leaves, respectively and also the number of the predators $S$. seriacus and $C$. vulgaris aegyptica 67-79 and 71-83 /30 leaves. Results in Table (2) indicate that in first year (2008), the two compounds Biofly and NeemAzal gave moderate effect against adults and nymphs of $M$. hirsutus after 15 days. They also showed moderate toxic effect against the parasitoids, $A$. kamali and $A$. pseudococci and $A$. mecrida and the 
predators, S. seriacus and C. vulgaris aegyptica. On the other hand, Super Mesrona oil and Sumithion gave high efficacy against all targets after 15 days from application.

\subsection{The second season (2009)}

In the second season (2009), the pre-spraying counts of adults and nymphs of M. hirsutus were 872-895 and 2745-2820 / 30 leaves, respectively and the numbers of A. kamali and A. pseudococci and A. mecrida were 198-227, 179-201 and 197-231 /30 leaves, respectively and also the number of the predators $S$. seriacus and $C$. vulgaris aegyptica 82-94 and 100-123 /30 leaves. Results in Table (3) indicate that in first year (2008), the two compounds Biofly and NeemAzal gave moderate effect against adults and nymphs of $M$. hirsutus after 15 days. They also showed moderate toxic effect against the parasitoids, $A$. kamali and $A$. pseudococci and $A$. mecrida and the predators, $S$. seriacus and $C$. vulgaris aegyptica. On the other hand, Super Mesrona oil and Sumithion gave high efficacy against all targets after 15 days from application.

In the present work, Sumithion gave high efficacy against all targets. nymphs and adult of $M$. hirsutus were reduced by $91 \& 96$ and $88 \& 93 \%$ during the first and second years, respectively. Reduction in $A$. kamali and $A$. pseudococci and $A$. mecrida were $95,90,93 \%$ and $93,87,90 \%$, during the first and second years, respectively. While Mani and Krishnamoorthy (1990) in laboratory trials at field application rates, quinalphos $(0.05 \%)$, endosulfan $(0.07 \%)$, malathion $(0.1 \%)$, carbaryl $(0.1 \%)$ and fenthion $(0.1 \%)$ were toxic to the parasitoid, Anagyrus dactylopii that were reared on M. hirsutus on grapes. Also Persad and Khan (2000) tested five commonly insecticides, lambda-cyhalothrin, pirimiphos-methyl, triazophos, fipronil and decamethrin [deltamethrin] in the laboratory and under semi-field conditions for comparative effects on the mealybug and its exotic natural enemy complex. Adult $M$. hirsutus were more tolerant to all insecticides tested while the 1st instar stage was least tolerant. Chemical control was best achieved using either pirimiphos-methyl or triazophos on the 1st instar stage. Anagyrus kamali was most susceptible to all insecticides tested. Fipronil was also least persistent (LT50 value of 7 days) for $A$. kamali in the field. Later Raguramananmd and Premalatha (2006) observed the results indicated that methomyl (LannateR $40 \mathrm{SP}$ ) at 500-800 $\mathrm{g}$ ai/ha was effective in containing the populations of mealy bug, M. hirsutus, on grapes from December to April and from April to August. Methomyl 300-600 g ai/ha registered higher population of predatory coccinellids than other treatments in both the trials, however, it was not comparable with the untreated control. On the other hand, better recolonization of coccinellids was noticed in methomyl treatments than in dimethoate. While in the present work the predators $S$. seriacus and $C$. vulgaris aegyptica, the percent reduction were $88 \& 85$ and $84 \& 82$, during the first and second years, respectively, 
86 THE EFFICACY OF SOME NATURAL AND CHEMICAL FORMULATIONS AGAINST THE HIBISCUS MEALYBUG, MACONELLICOCCUS HIRSUTUS AND ITS NATURAL ENEMIES IN THE LABORATORY AND FIELD IN EGYPT

after 15 days from application. Srinivasan and Sundarababu (1989) tested the toxicity of 12 insecticides in sprays on grapevines to C.montrouzieri preying on M.hirsutus in the laboratory. The relative toxicity, as indicated from a persistence-toxicity index, was in the descending order monocrotophos, parathion-methyl, malathion, dimethoate, quinalphos, phosalone, dichlorvos, demeton-methyl, wettable sulfur, agricultural spray oil, Bordeaux mixture and fish oil resin soap. When insecticide-contaminated prey was provided, toxicity was quite high. Mani and Thorntakarya (1988) tested sixteen pesticides for their toxicity to the encyrtid parasitoid $A$. dactylopii and the coccinellid predator Scymnus coccivora, in India. Dichlorvos, diazinon, phosalone and fish oil resin soap were found to be non-toxic to $A$. dactylopii, while all the insecticides tested proved harmful to $S$. coccivora. However, copper oxychloride, mancozeb, sulfur, carbendazim, Bordeaux mixture and dicofol were safe to both natural enemies. Babu and Azam (1987) stated that Dichlorvos at $0.1 \%$ was found to be the safest insecticide on the predacious coccinellid C. montrouzieri attacking M.hirsutus on grapevines ; synthetic pyrethroids were highly toxic and more persistent. In the present work the effect of Sumithion, predators S. seriacus and C. vulgaris aegyptica (78 \&75 and 84\&82), respectively, after 15 days from application. 
Table 1. LC values of the tested compounds against different stages of $M$. hirsutus and its natural enemies under laboratory conditions.

\begin{tabular}{|c|c|c|c|c|}
\hline Stages & Compound & $\mathrm{LC}_{50}$ & $\mathrm{LC}_{90}$ & Slope \\
\hline \multirow{4}{*}{ Nymphs } & Biofly & 0.517 & 12.605 & 0.924 \\
\hline & NeemAzal & 0.764 & 29.427 & 0.808 \\
\hline & Super Mesrona oil & 5.254 & 15.37 & 2.749 \\
\hline & Sumithion & 0.152 & 1.14 & 1.466 \\
\hline \multirow{4}{*}{ Adult females } & Biofly & 2.009 & 62.62 & 0.858 \\
\hline & NeemAzal & 3.205 & 178.025 & 3.205 \\
\hline & Super Mesrona oil & 6.903 & 29.002 & 2.056 \\
\hline & Sumithion & 0.188 & 2.169 & 1.206 \\
\hline \multirow{4}{*}{ Anagyrus kamali } & Biofly & 3.869 & 94.336 & 0.924 \\
\hline & NeemAzal & 5.893 & 229.857 & 0.805 \\
\hline & Super Mesrona oil & 7.67 & 36.829 & 1.881 \\
\hline & Sumithion & 0.298 & 3.735 & 1.168 \\
\hline \multirow{4}{*}{ A. pseudococci } & Biofly & 9.686 & 479.284 & 0.756 \\
\hline & NeemAzal & 3.138 & 195.492 & 0.714 \\
\hline & Super Mesrona oil & 8.447 & 38.187 & 1.956 \\
\hline & Sumithion & 0.282 & 4.245 & 1.089 \\
\hline \multirow{4}{*}{ Allotropa mecrida } & Biofly & 7.609 & 282.316 & 0.817 \\
\hline & NeemAzal & 4.265 & 247.265 & 0.726 \\
\hline & Super Mesrona oil & 9.285 & 40.475 & 2.004 \\
\hline & Sumithion & 0.211 & 6.344 & 0.868 \\
\hline \multirow{4}{*}{ Scymnus seriacus } & Biofly & 6.702 & 161.418 & 0.928 \\
\hline & NeemAzal & 10.106 & 547.329 & 0.739 \\
\hline & Super Mesrona oil & 12.043 & 82.378 & 1.535 \\
\hline & Sumithion & 0.304 & 5.228 & 1.037 \\
\hline \multirow{4}{*}{ Chrysopa vulgaris } & Biofly & 6.702 & 161.418 & 0.928 \\
\hline & NeemAzal & 10.106 & 547.329 & 0.739 \\
\hline & Super Mesrona oil & 13.455 & 82.556 & 1.627 \\
\hline & Sumithion & 0.344 & 4.755 & 1.124 \\
\hline
\end{tabular}


88 Egypt. J. Agric. Res., 89 (1), 2011

Table 2. 
Table 3. 
90 THE EFFICACY OF SOME NATURAL AND CHEMICAL FORMULATIONS AGAINST THE HIBISCUS

MEALYBUG, MACONELLICOCCUS HIRSUTUS AND ITS NATURAL ENEMIES IN THE LABORATORY AND FIELD IN EGYPT 
92 THE EFFICACY OF SOME NATURAL AND CHEMICAL FORMULATIONS AGAINST THE HIBISCUS

MEALYBUG, MACONELLICOCCUS HIRSUTUS AND ITS NATURAL ENEMIES IN THE LABORATORY AND FIELD IN EGYPT 
94 THE EFFICACY OF SOME NATURAL AND CHEMICAL FORMULATIONS AGAINST THE HIBISCUS

MEALYBUG, MACONELLICOCCUS HIRSUTUS AND ITS NATURAL ENEMIES IN THE LABORATORY AND FIELD IN EGYPT 
96 THE EFFICACY OF SOME NATURAL AND CHEMICAL FORMULATIONS AGAINST THE HIBISCUS

MEALYBUG, MACONELLICOCCUS HIRSUTUS AND ITS NATURAL ENEMIES IN THE LABORATORY AND FIELD IN EGYPT 
98 THE EFFICACY OF SOME NATURAL AND CHEMICAL FORMULATIONS AGAINST THE HIBISCUS

MEALYBUG, MACONELLICOCCUS HIRSUTUS AND ITS NATURAL ENEMIES IN THE LABORATORY AND FIELD IN EGYPT 
100 THE EFFICACY OF SOME NATURAL AND CHEMICAL FORMULATIONS AGAINST THE HIBISCUS

MEALYBUG, MACONELLICOCCUS HIRSUTUS AND ITS NATURAL ENEMIES IN THE LABORATORY AND FIELD IN EGYPT 
102 THE EFFICACY OF SOME NATURAL AND CHEMICAL FORMULATIONS AGAINST THE HIBISCUS MEALYBUG, MACONELLICOCCUS HIRSUTUS AND ITS NATURAL ENEMIES IN THE LABORATORY AND FIELD IN EGYPT

\section{REFERENCES}

1. Abbot, W.S. 1925. A method of computing the effectiveness of an insecticide. J. Econ. Entomol.,18: 265-267.

2. Abd-Rabou, S. 2000. Parasitoids attacking the hibiscus mealybug, Maconellicoccus hirsutus (Green) (Homoptera: Pseudococcidae) in Egypt. Proceedings of the Scientific Conference of Agricultural Sciences, Faculty of Agric. Assiut Univ. Vol. II: 661-666.

3. Abd-Rabou, S. 2005. The effect of augmentative releases of indigenous parasitoid, Anagyrus kamali ( Hymenoptera : Encyrtidae) on populations of Maconellicoccus hirsutus (Hemiptera : Pseudococcidae) in Egypt. Archives of Phytopathology and Plant Protection,38(2): 129-132.

4. Abd-Rabou,S., H. Badary and N. Ahmed. 2007. An annotated list of natural enemies of the pink hibiscus mealybug Maconellicoccus hirsutus ( Homoptera : Pseudococcidae) in Egypt. Egypt.J. Appl. Sci., 22(B): 612-616.

5. Babu, T.R. and K.M. Azam. 1987. Influence of some pesticides on the egg and larval stages of the mealybug predator, Cryptolaemus montrouzieri Mulsant (Coccinellidae: Coleoptera). Indian Journal of Plant, 15(1): 109-112 .

6. Finney, D. J. 1971. Probit analysis, Cambridge University Press. $3^{\text {rd }}$ Edn., pp.333.

7. Henderson, C. F. and E.W. Tilton. 1955. Tests with acaricides against the brown wheat mite. J. Econ. Entomol., 48(2): 157-161.

8. Mani, M. 1989. A review of the pink mealybug, Maconellicoccus hirsutus (Green). Insect Sci. Applic., 10:157-167.

9. Mani, M. and A. Krishnamoorthy .1990. Further studies on the safety of pesticides to Anagyrus dactylopii (Hym., Encyrtidae) and Cryptolaemus montrouzieri (Coleop., Coccinellidae). Journal of Biological Control, 4(2): 80-85. .

10. Mani, M. and T.S. Thorntakarya .1988. Studies on the safety of different pesticides to the grape mealybug natural enemies, Anagyrus dactylopii (How.) and Scymnus coccivora Ayyar.Indian Journal of Plant Protection, 16(2): 205-210.

11. Muthukrishnan, N., T. Manoharan, P.S.T. Thevan and S. Anbu. 2005. Evaluation of buprofezin for the management of grape mealy bug, Maconellicoccus hirsutus (Green) .Journal of Entomological Research, 29(4): 339-344.

12. Noyes, J.S. and M.Hayat .1994. Oriental mealybug parasitoids of the Anagyrini (Hymenoptera: Encyrtidae). CAB International Wallingford Oxon , UK. 532pp.

13. Persad, A. and A.Khan .2000. The effect of five insecticides on Maconellicoccus hirsutus (Green) (Homoptera: Pseudococcidae) and its natural enemies Anagyrus kamali Moursi (Hymenoptera: Encyrtidae), and Cryptolaemus montrouzieri mulsant 
and Scymnus coccivora aiyar (Coleoptera: Coccinellidae). International Pest Control, 42(5): 170-173.

14. Raguraman, S. anmd K. Premalatha .2006. Field evaluation of methomyl against mealy bug, Maconellicoccus hirsutus (Green) and predatory coccinellid, Cryptolaemus montrouzieri Mulsand in grapes. Pesticide Research Journal, 18(1): 28-30.

15. Reddy, G.V.P., R. Muniappan, Z.T.Cruz, F. Naz, J.P. Bamba and J.Tenorio. 2009. Present Status of Maconellicoccus hirsutus (Hemiptera: Pseudococcidae) in the Mariana Islands and Its Control by Two Fortuitously Introduced Natural Enemies. Journal of Economic Entomology, 102 ( 4): 1431-1439.

16. Satyanarayana, J., M.S. Murthy and N. Srinivasa. 1991. Impact of pesticides on grapevine mealybug predator, Cryptolaemus montrouzieri Mulsant. 1. Residual toxicity and safety of pesticidal sprays to predatory grubs. Indian Journal of Entomology,53(4): 587-592.

17. SAS Institute. 1988. SAS/STAT User's Guide, Ver. 6.03. SAS Institute Inc., Cary, North Carolina.

18. Srinivasan, T.R. and P.C. Sundarababu . 1989. Toxicity of insecticides to Cryptolaemus montrouzieri Mulsant. South Indian Horticulture, 37(4): 254-257.

19. Williams, D. J. 1996. A brief account of the hibiscus mealybug Maconellicoccus hirsutus (Hemiptera: Pseudococcidae), a pest of agriculture and horticulture, with descriptions of two related species from southern Asia. Bull. Entomol. Res. 86: 617-628. 
تاثير بعض المركبات الكيميائية و الطبيعية على بق الهببكس الاقيقى و أعدائه الحيوية فى المعمل و الحقل

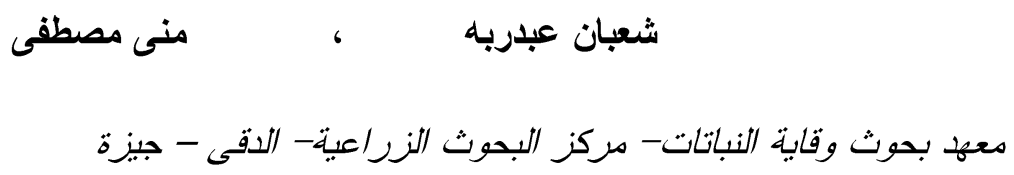

يعتبر بق الهبسكس الدقيقى من أهم الآفات التى تصيب العنب و الجوافة و فول الصويا و

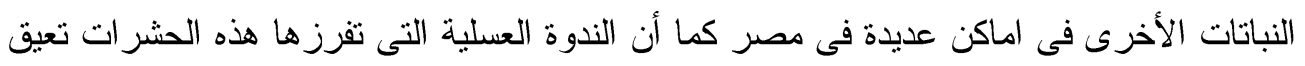

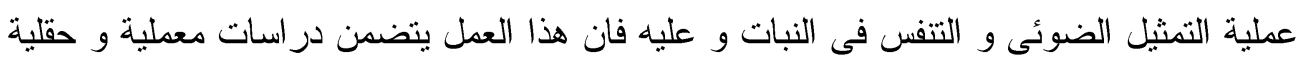
على تاثثر بعض المركبات الطبيعية ( البيوفلاى و النيماز ال و زيت سوبر مصرونا) و المركبات الكيميائية (السومثيون) على بق الهبسكس الدقيقى و طفيلياته و مفترساته وقد أنضح من النتائج

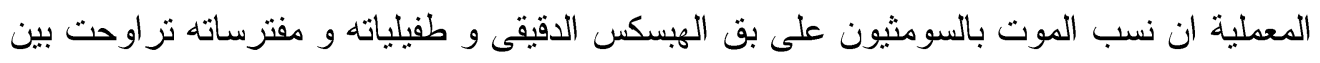

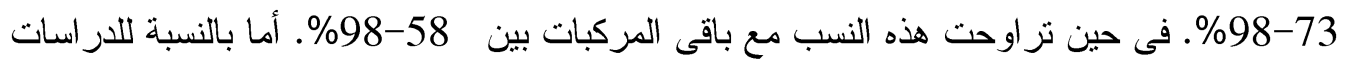

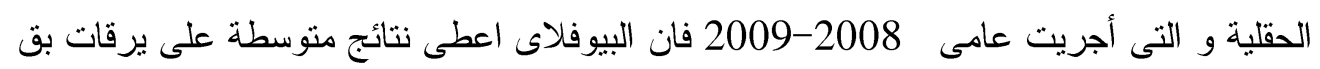
الهبسكس الدقيقى مسجلا معدلات موت قدرها 41 و 36 \% بعد ثلاثة أيام من الرش و 55 و و 51 و 51 \%

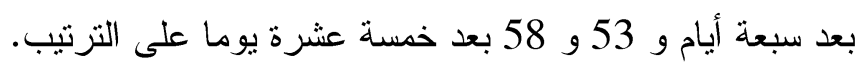
أما بالنسبة للطقيليات : بات و و

Anagyrus kamali, Anagyrus pseudococci, Allotropa mecrida

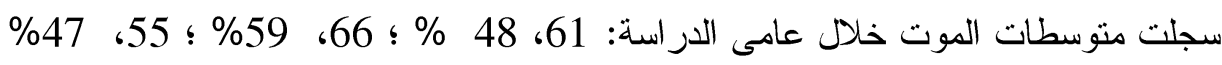

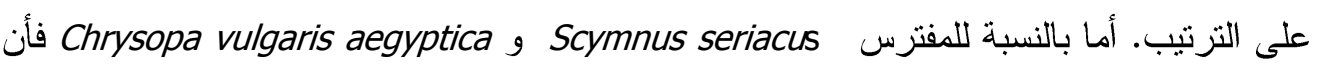

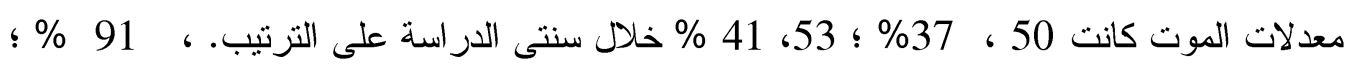
93، 88\% في عامى 2008-2009 على الجانب الأخر فان مركب السومثيون سجل نسب موت قدرها 96، 91 \% ؛ 93، 88\% فى عامى عامى 2008-2009 على الحوريات و الحشرة الكاملة لبق

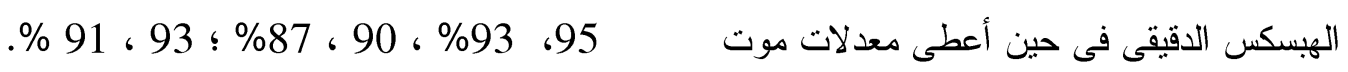
Anagyrus kamali, Anagyrus pseudococci, Allotropa mecrida

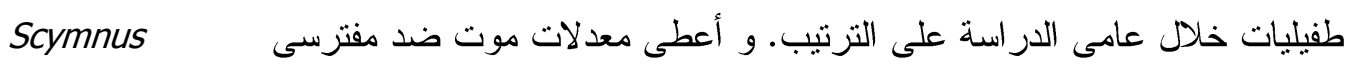

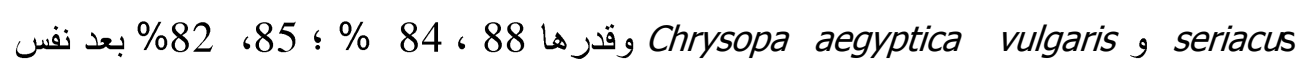
الفترة من المعاملة. 